\section{Foster care: extend services, save youth}

Re: "Health care for foster kids: Fix the system, save the child." ${ }^{1}$ We would like to draw attention to homelessness as an all-too-frequent outcome for youth in foster care. In a recent study of urban homeless youth, we found that $42.7 \%$ were once involved with a Children's Aid Society. ${ }^{2}$ In addition to the excellent recommendations made in the editorial, we want to add the need for a change in policy regarding the use of the age of majority as the primary criterion for determining discontinuation in foster care and access to services. Youth exiting the system are at an age of development characterized by instability and most are unprepared for independent living, yet forced out based on an arbitrary administrative criterion. Recent statistics indicate that $43.5 \%$ of Canadians age 20 to 29 are living at home with their parents. ${ }^{3}$ Surely youth in foster care deserve the same opportunity for stability? As acting parents of youth in foster care, the government needs to take its role to heart and reconsider its policy of forcing at-risk youth out of the system and, in many cases, onto the streets.

\section{Abby L. Goldstein PhD}

Ontario Institute for Studies in Education,

University of Toronto, Toronto, Ont.

Patricia Erickson PhD

Centre for Addiction and Mental Health,

Toronto, Ont.

Christine Wekerle PhD

McMaster University, Hamilton, Ont.

\section{REFERENCES}

1. Hébert PC, MacDonald N. Health care for foster kids: Fix the system, save a child. CMAJ 2009;181: 453.

2. Fidler T, Wekerle C, Erickson P. The Youth Pathways Project (YPP): Childhood maltreatment and health outcomes among Toronto street-involved youth. OACAS Journal 2008;52:25-32.

3. Family portrait: continuity and change in Canadian families and households in 2006. 2006 Census analysis. Ottawa (ON): Statistics Canada; 2007. Cat. no. 97-553-XIE.

For the full letter, go to: www.cmaj.ca/cgi/eletters /181/8/453\#230603

DOI:10.1503/cmaj.109-2046

\section{H1N1 and remote locations}

The scenario in remote and underserved locations in Canada regarding specific diagnosis and antiviral therapeutic response ${ }^{1}$ seems to mimic the picture in developing countries. Even the largest cities do not have facilities for a specific and accurate diagnosis of pandemic H1N1(2009) influenza infection. Molecular or cell culture studies would never be a reality. A specific diagnosis should be feasible through rapid, simple, 1-2 step assays that could be carried out in physicians' surgeries and in the field. Certainly "contact persons" in remote and underserved areas in Canada should be able to carry out such tests using naso-pharyngeal secretions. Funds should be directed toward standardization of such test kits to allow an accurate diagnosis of H1N1. Such kits will be of immense value in Canada; they would be the only test for billions in developing countries.

\section{Subhash C. Arya MBBS PhD \\ Nirmala Agarwal \\ Sant Parmanand Hospital, Delhi, India}

\section{REFERENCES}

1. Kondro W. Dispensing antivirals in underserved communities. CMAJ 2009;181:E199-200.

For the full letter, go to: www.cmaj.ca/cgi/eletters /181/9/E199\#228488

DOI:10.1503/cmaj.109-2047

\section{Values-based health care debate, not statistics}

Although the main focus of "America, embrace health care reform" ${ }^{1}$ revolves around finances, the editorial lacks 'values.' The Canadian health care plan is a statement of Canadian values: that its citizens, regardless of ability, are equally deserving of the opportunity for good health care. By focusing on the economics, Dr. Attaran and his colleagues have lost the essence of what is at issue. A change from private to public health care represents a fundamental shift in the expression of American principles. Conservatives and those against univer- sal health care in America have learned the importance of framing the debate in terms of their values. If progressives are to eventually succeed, they must reframe the debate in terms of their values, instead of $p$ values and percentages.

\section{Henry J. Conter}

Internal medicine resident, University of Alberta, Edmonton, Alta.

\section{REFERENCES}

1. Attaran A, Stanbrook MB, Hébert PC. America, embrace health care reform. CMAJ 2009;181: E128-9.

For the full letter, go to: www.cmaj.ca/cgi/eletters /181/8/E128\#228490

DOI:10.1503/cmaj.109-2048

\section{Embrace, don't cope}

Re: "Coping with public health 2.0." People want to make informed choices about their health conditions. In response, a vast network of web-based information is in place, including the formidable website of the Public Health Agency of Canada. Many of these websites now host interactive online support groups, often supported by health care professionals. Those who use online content are engaged; they are taking steps to manage their own conditions. If it also happens that their discussions are taking up clinical time, then physicians could send them to a nurse educator. Web 2.0 is an arena of communication. If public health officials have a concern about a medical counterculture movement then it may be more useful to look at the causes and drivers and not at the channel.

\section{George Klima}

eHealth Research Unit, Faculty of Medicine, Memorial University of Newfoundland, St. John's, NL

\section{REFERENCE}

1. Wilson k, Keelan J. Coping with public health 2.0 . CMAJ 2009; 180:1080.

For the full letter, go to: www.cmaj.ca/cgi/eletters /180/10/1080\#233909

DOI:10.1503/cmaj.109-2052 